\title{
O CAPITALISMO COMO RELIGIÃO: A CULPA
}

\author{
Josué Cândido da Silva
}

\begin{abstract}
RESUMO
As relações entre o capitalismo e religião foram analisadas na famosa obra de Max Weber, A ética protestante e o espírito do capitalismo, publicada em sua forma definitiva em 1920. Um ano mais tarde, Walter Benjamin elaborou um instigante esboço sobre o tema, um verdadeiro roteiro de pesquisa que nunca veio a ser concretizado e cujo manuscrito veio a lume na edição de suas obras completas em 1985. Com o título Capitalismo como religião, Benjamin vai além de Weber ao afirmar que não só os elementos da ética protestante deram impulso ao capitalismo nascente, mas que o próprio capitalismo, como um todo, deve ser visto como uma religião. Segundo Benjamin, um dos traços da forma religiosa do capitalismo é o de não ser uma religião de redenção e sim de culpabilização, cujo culto, ao invés de expiar a culpa, a intensifica, expandindo o desespero humano ao estado religioso universal. Nesse sentido, nosso artigo visa analisar a influência do conceito cristão de culpa na estrutura religiosa do capitalismo e como a permanente culpabilização tornou-se um elemento fundamental do mecanismo de reprodução do sistema capitalista. Além disso, apresentaremos a crítica de Benjamin às concepções de eterno retorno de Nietzsche e de progresso do marxismo vulgar como visões míticas do destino na história, incapazes de oferecerem uma alternativa emancipadora ao capitalismo.
\end{abstract}

Palavras-chave: Capitalismo como religião. Culpa. Ética protestante

\section{CAPITALISM AS RELIGION: THE BLAME}

\begin{abstract}
The relationship between capitalism and religion was analyzed in Max Weber's famous work, The Protestant Ethics and the Spirit of Capitalism, published in its definitive form in 1920. One year later, Walter Benjamin produced an intriguing sketch on the subject, a true research script that he never accomplished and whose manuscript came to light in the edition of his complete works in 1985. With the title Capitalism as religion, Benjamin goes beyond Weber in claiming that not only the elements of Protestant ethics gave impetus to capitalism, but that capitalism itself as a whole must be seen as religion. According to Benjamin, one of the hallmarks of the religious form of capitalism is that it is not a religion of redemption but of blame, whose worship, rather than atone for guilt, intensifies it, expanding human despair to the universal religious state. In this sense, our paper aims to analyze the influence of the Christian concept of guilt on the religious structure of capitalism and how permanent blame has become a fundamental element of the reproduction mechanism of the capitalist system. In addition, we will present Benjamin's critique of Nietzsche's conceptions of eternal return and
\end{abstract}


the progress of vulgar Marxism as mythical visions of fate in history, unable to offer an emancipatory alternative to capitalism.

Key-words: Capitalism as a religion. Guilt. Protestant ethics

As relações entre o capitalismo e religião foram analisadas na famosa obra de Max Weber, A ética protestante e o espírito do capitalismo, publicada em sua forma definitiva em 1920. Um ano mais tarde, Walter Benjamin elaborou um instigante esboço sobre o tema, um verdadeiro roteiro de pesquisa que nunca veio a ser concretizado e cujo manuscrito veio a lume na edição de suas obras completas, organizada por Ralph Tiedemann e Hermann Schweppenhäuser, em 1985. Com o título Capitalismo como religião, Benjamin vai além de Weber ao afirmar que não só os elementos da ética protestante deram impulso ao capitalismo nascente, mas que o próprio capitalismo, como um todo, deve ser visto como uma religião. Para demonstrar sua tese, Benjamin enumera quatro traços que podem ser identificados na estrutura religiosa do capitalismo.

Primeiro, ser uma religião só de culto, cuja duração é permanente. "Nele, todas as coisas só adquirem significado na relação imediata com o culto; ele não possui nenhuma dogmática, nenhuma teologia. Sob esse aspecto, o utilitarismo obtém sua coloração religiosa." (BENJAMIN, 2013, 21).

A segunda característica é a duração permanente do culto. "O capitalismo é a celebração de um culto sans trêve et sans merci [sem trégua e sem piedade]. Para ele, não existem 'dias normais', não há dia que não seja festivo no terrível sentido da ostentação de toda a pompa sacral, do empenho extremo do adorador." (Idem, 21-22). Benjamin ironiza a critica protestante de que no calendário católico há um excesso de dias santos, já no capitalismo não existiriam "dias normais". Ou seja, o culto ocorre o tempo todo, ou melhor, a medida do tempo em dinheiro permite que o culto prossiga em um fluxo contínuo, seja na forma de investimentos e rentabilidade do capital, seja no culto às mercadorias, em que cada aspecto da vida é preenchido por relações de consumo.

Um terceiro traço é que esse culto não é expiatório, mas culpabilizador, ou seja, o culto não elimina a culpa, mas a torna universal. 
Nesse aspecto, tal sistema religioso é decorrente de um movimento monstruoso. Uma monstruosa consciência de culpa que não sabe como expiar lança mão do culto, mas para torná-la universal, para martelá-la na consciência e, por fim, e acima de tudo, envolver o próprio Deus nessa culpa, para que ele se interesse pela expiação. (Idem, 22).

Por fim, o quarto traço dessa religião é que seu Deus precisa ser ocultado. O Deus a que se presta culto, o capital, é o grande sujeito do sistema que coloca as relações capitalistas de produção em movimento, que produz ganhos e catástrofes econômicas e ambientais, mas que simplesmente não aparece como sujeito na naturalização do sistema realizada por seus adoradores. Assim, vários ídolos tomam seu lugar como sua forma fantasmagórica: dólar, bolsa, mercado... que ocupam os noticiários manifestando diferentes estados de humor, como ocorre com as variações do clima.

Nessa caracterização, o conceito de culpa ocupa um lugar central, até mesmo pela sua "demoníaca ambiguidade", como se refere Benjamin ao fato de que em alemão Schuld significa, ao mesmo tempo, "culpa" e "dívida", o que trás uma dificuldade a mais na tradução e interpretação do esboço. O presente artigo investiga as origens religiosas da estrutura de culpabilização no capitalismo e de como esta estrutura atua como mecanismo essencial para reprodução do sistema. Para tanto, analisaremos o conceito de culpa em outras obras de Walter Benjamin do mesmo período, para delimitar mais claramente seus contornos. Em seguida, veremos como tal conceito evoluiu na teologia cristã e se tornou o eixo central do modo capitalista de vida, ou seja, como ocorreu a secularização, ou, para usar o conceito de Giorgio Agamben, a profanação do campo religioso tornado cotidiano, isto é, como se deu a amálgama entre o campo sagrado e profano através do mecanismo da culpabilização no capitalismo.

\section{0 conceito de culpa}

Uma das chaves para elucidação do conceito de culpa em Walter Benjamin é o texto, também de 1921, Destino e caráter. Nele, Benjamin discute a possibilidade da liberdade como pressuposto da ética e a falsidade da relação causal entre destino e caráter, já que o caráter é referido indevidamente como Doutor em Filosofia pela PUC-SP e professor titular da Universidade Estadual de Santa Cruz UESC. Brasileiro, residente em Ilhéus - Bahia. Email: josil@uesc.br 
causa do destino. Ou seja, se conhecêssemos o caráter de uma pessoa em todos os seus pormenores seria possível prever exatamente o seu destino, pois o sujeito só realiza o que seu caráter determina, como algo pré-estabelecido. Nesse sentido, os sinais do caráter seriam algo reconhecível, o que permitiria a previsão do destino para quem é capaz de ler os sinais, por exemplo, nas mãos e também nos sinais exteriores ao corpo como no horóscopo.

Esta possibilidade de relação causal é contestada por Benjamin, pois os sinais do caráter estão ligados ao corpo enquanto os do destino atingem a vida exterior. Por outro lado, há uma ação recíproca entre o indivíduo e o mundo, de modo que não se pode estabelecer uma relação causal entre ambos. "Entre este indivíduo e o mundo exterior tudo é, pelo contrário, ação recíproca, os seus campos de ação interpenetram-se; por mais que as suas ideias sejam diferentes, os seus conceitos não são separáveis" (BENJAMIN, 2011, 6).

Para evitar a superposição entre os conceitos é preciso colocá-los devidamente nas esferas de onde se originam. "O caráter é geralmente colocado num contexto ético, e o destino num contexto religioso" (BENJAMIN, 2011, 6). Portanto, não há como realizar uma vinculação entre eles, já que pertencem a domínios diferentes. O fato do conceito de destino ter se deslocado para o campo religioso ocorreu por outra conexão que deu origem ao erro. "Tal erro deve-se à relação estabelecida, no caso do conceito de destino, entre este e o de culpa" (BENJAMIN, 2011, 6-7). A origem dessa imbricação entre destino e culpa corresponde à ideia clássica grega do indivíduo sempre sujeito a cair em uma culpa grave, na hybris. Um exemplo disso é citado por Benjamin no texto Para uma crítica da violência, de 1921. Trata-se do mito de Níobe que provoca a ira da deusa Leto que só tinha dois filhos, Apolo e Artemis, enquanto Níobe se gabava de ter quatorze, sete filhos e sete filhas. Enfurecida, a deusa manda que seus filhos matem todos os filhos de Níobe. O orgulho de Níobe que atrai a violência dos deuses não desafia o direito, mas o destino, que sempre sai vitorioso. Matando seus filhos, mas a deixando viva, a deusa a torna "mais culpada que antes, quase um eterno e mudo sustentáculo da culpa, marco entre os homens e os deuses" (BENJAMIN, 1995, 38). O contrário dessa perspectiva é que se há salvação possível, o destino não pode ser considerado como algo religioso. Como observa Benjamin, 
uma ordem cujos únicos conceitos constitutivos sejam a desgraça e a culpa, e da qual se exclua a possibilidade de um caminho de salvação (pois a partir do momento em que algo se transforma em destino é desgraça e culpa) - uma tal ordem não pode ser religiosa, por mais que o conceito de culpa, falsamente compreendido, para aí pareça remeter" (BENJAMIN, 2011, 7)

E qual seria o domínio em que destino e culpa se confundem sem que haja possibilidade de redenção? "O Direito eleva as leis do destino, a desgraça e a culpa, à categoria de medidas da pessoa humana" (BENJAMIN, 2011, 7). O Direito dialeticamente, ao tentar vencer os demônios da religião, acaba por secularizá-los através dos códigos que determinam as relações entre os homens. "Por tanto, no fundo, o sujeito não tem um destino, mas o sujeito do destino é como tal indeterminável. O juiz pode descortinar destino onde quiser, e ditará às cegas um destino com cada condenação" (BENJAMIN, 2011, 9).

A culpa se torna naturalizada e, dessa forma, previsível e reconhecível, da qual o indivíduo é apenas um caso exemplar. Cada condenação é uma repetição de casos anteriores e os casos futuros também trazem consigo o índice do passado. O tempo do Direito, como o tempo mítico, torna-se eterno retorno. Como forma invariante do destino, a culpa "insere-se de forma muito imprópria no fluxo do tempo, na sua natureza e na sua medida totalmente diferente do tempo da redenção ou da música ou da verdade" (BENJAMIN, 2011, 9). Em um texto anterior, Drama barroco e tragédia, de 1916, Benjamin faz a mesma comparação ao se referir ao tempo do trágico. "A relação entre o tempo trágico e o tempo messiânico é a mesma que existe entre o tempo individualmente preenchido e o tempo divinamente preenchido" (BENJAMIN, 2013, 60). O tempo preenchido individualmente é o tempo que inscreve todos os feitos da existência inteira do herói trágico dentro de um círculo mágico que é dominado pelo horizonte da culpa, em que qualquer deslize pode levar o herói à condenação. $O$ tempo messiânico, ao contrário, rompe com a forma naturalizada do destino trágico e se apresenta como possibilidade de redenção do passado e ruptura do tempo homogêneo da repetição infinita. Este tempo que é abertura para liberdade, Benjamin o vê como possibilidade na comédia em que o indivíduo se revela não como uma moralidade exemplar, mas na singularidade de seu caráter.

Enquanto o destino desdobra a imensa compilação da personagem culpada, a complicação e as relações dessa culpa, o caráter responde Doutor em Filosofia pela PUC-SP e professor titular da Universidade Estadual de Santa Cruz UESC. Brasileiro, residente em Ilhéus - Bahia. Email: josil@uesc.br 
com o gênio àquela sujeição mítica da personagem à trama da culpa. A complicação torna-se simplicidade, o fado liberdade. Pois o caráter da personagem cômica não é o espantalho dos deterministas, é o farol a cuja luz se torna visível a liberdade dos seus atos (BENJAMIN, 2011, 12).

\section{0 desenvolvimento de um parasita}

Em um dos apontamentos de $O$ capitalismo como religião, Benjamin afirma que no Ocidente o capitalismo se desenvolveu como um parasita dentro do cristianismo, de tal forma que a história do cristianismo se tornou a história desse parasita. Portanto, "metodologicamente, precisaríamos investigar que conexões estabeleceu, em cada momento ao longo da história, o dinheiro com o mito, até o ponto de atrair para si tantos elementos míticos do cristianismo e constituir a si próprio um mito" (HINKELAMMERT, 2007, 169). Partindo dessa hipótese de trabalho, cabe reconstruir as principais etapas desse desenvolvimento em que o cristianismo foi se transformando, ele próprio, em um mito culpabilizador para, finalmente, florescer em seu interior a forma secularizada da religião do dinheiro, ou seja, o capitalismo.

Mas como a religião inspirada nos ensinamentos de Jesus de Nazaré, que dizia que não se pode servir a Deus e ao dinheiro, pôde transformar-se em seu inverso? Benjamin nunca chegou a desenvolver essa hipótese, deixando apenas algumas pistas de que caminho pretendia percorrer em sua investigação. $\mathrm{Na}$ tentativa de dar corpo a esse projeto podemos tentar remontar o caminho que levou o cristianismo a tornar-se, ele próprio, um mito. Ou seja, como o cristianismo opera a naturalização da culpa ao conectar, como antes já o haviam feito o mito e o Direito, destino e culpa em um único conceito. No caso da teologia cristã, esse processo se desenvolve através do conceito de pecado original desenvolvido por santo Agostinho e aprimorado por santo Anselmo.

Ao contrário do universo mítico grego em que a culpa é naturalizada, no judaísmo, a culpa tem uma conotação moral. O pecado e, consequentemente, a culpa são resultado da quebra do contrato do homem com Deus. Para reconciliar-se com Deus o homem deve fazer um sacrifício a Deus. Ocorre que 
a culpa/dívida do homem para com Deus resulta do não cumprimento da lei. $\mathrm{Na}$ lei, como já vimos, há a naturalização da culpa, porém essa se torna invisibilizada pela associação entre cumprimento da lei e justiça. Assim, a possibilidade de redenção, mesmo que aparentemente oferecida ao pecador através do sacrifício, apenas o culpabiliza ainda mais, como observa o autor da Carta aos Hebreus:

\begin{abstract}
A Lei possui apenas uma sombra dos bens futuros, e não a realidade concreta das coisas. Por isso, mesmo oferecendo sacrifícios continuamente, ano após ano, a Lei não tem poder de conduzir à perfeição aqueles que participam de tais sacrifícios. Caso contrário, será que não se teria parado de oferecer esses sacrifícios? De fato, os fiéis, purificados uma vez por todas, doravante não teriam mais nenhuma consciência dos pecados. Contudo, por meio desses sacrifícios, a lembrança dos pecados é renovada ano após ano, uma vez que é impossível eliminar os pecados com o sangue de touros e bodes. (Hb 10, 1-4).
\end{abstract}

O autor mostra aqui a dialética perversa em que ao invés de expiar a culpa, o sacrifício a reforça. Em um ciclo interminável, ano após ano, os novos sacrifícios são incapazes de redimir a dívida pelo descumprimento da Lei. Assim, a religião em seu ciclo: pecado-culpa-sacrifício permanece como redenção apenas na aparência, pois, na verdade, serve para reforçar o pecado e a culpa.

Jesus percebe o limite da Lei e de sua impossibilidade de redimir 0 pecador, pois nada do que ele faça o pode livrar de sua dívida para com Deus, mas insere aí um novo elemento: Deus deixa de cobrar a dívida. Na famosa oração do Pai Nosso, Jesus diz: "Perdoa as nossas dívidas assim como nós perdoamos aos nossos devedores" (Mt 6,12). Como observa Hinkelammert: "A dívida do homem com Deus - seus pecados -, é agora cobrar as dívidas que o homem tem com o outro. Que o homem tenha devedores, é a dívida que tem com Deus". (HINKELAMMERT, 1991, 60) Dessa forma, Deus não cobra a dívida, mas temos que dela prestar conta ao não perdoarmos a dívida que os outros têm conosco. Isso muda a lógica dos sacrifícios, os sacrifícios se pagam a Deus, mas Deus já não exige sacrifícios e sim perdão das dívidas. A dívida do homem para com Deus é impagável, mas a de nossos devedores não, ela é pagável. Ao darmos liberdade ao nosso devedor, Deus também nos liberta. Mas, ao contrário, se "o homem torna o outro dependente de si, ele, por sua vez, perde sua liberdade frente a Deus" (HINKELAMMERT, 1991, 60). 
Parece ser um movimento simples, mas que subverte toda teologia. $O$ pecado não se paga mais a Deus com sacrifícios, mas sim através do perdão das dívidas concretas de nossos devedores. Deus nos liberta quando libertamos o outro, não estamos mais presos à maldição que pesa sobre a Lei e à naturalização da culpa. Desse modo, há uma possibilidade efetiva de redenção que é introduzida pelo perdão de Deus, com a única condicionante de que rompamos também com a Lei que nos dá direito de cobrar e escravizar ao próximo 1 .

A proposta de Jesus se torna demasiado incômoda para ser assimilada pelo Império Romano e é duramente perseguida por este. Porém, quando Constantino torna o cristianismo a religião oficial do Império, várias adequações serão necessárias para que a própria Igreja, fundada por Constantino, possa também ela, cobrar dívidas, o que não é possível sem a universalização da culpa.

\section{0 pecado original e a universalização da culpa}

Devemos a santo Agostinho a primeira inversão da proposta de Jesus de salvação universal em culpabilização universal, ou seja, o pressuposto já não é mais a possibilidade do perdão das dívidas, mas a elevação a um estado permanente de devedores perante Deus. Segundo Paul Ricoeur, no esforço de combater a gnose, Agostinho acabou por deixar-se conduzir pelo próprio terreno da gnose, assim "a anti-gnose tornou-se uma quase-gnose" (RICOEUR, 2008, $5)$.

O gnosticismo do século II é um conjunto de sincretismos que tenta helenizar o cristianismo nascente a partir de algumas teses neoplatônicas. Uma delas é a de que o mundo não fora criado por Deus, mas pelo Demiurgo, este teria usado a matéria corruptível para formá-lo e, desta feita, o mal teria penetrado na Criação. O homem teria duas naturezas: a alma incorruptível e o

\footnotetext{
1 Essa mensagem é tão revolucionária, que no auge da dívida na América Latina, a Igreja Católica mudou a oração do Pai Nosso para "perdoai nossas ofensas, assim como perdoamos a quem nos tem ofendido". Concretamente, isso não nos livra nem da obrigação de pagarmos nossas dívidas e fazermos sacrifícios, tampouco liberta nossos devedores.
} 
corpo, feito de matéria corruptível, estando assim, condenado ao pecado. Desta forma, o pecado não é resultado de uma falta moral do homem, mas algo natural, uma maldição lançada sobre nós pelo erro do Demiurgo que nos criou.

De igual modo, o pecado que o homem confessa é menos o acto de malfazer, da mal-feitoria, que o estado de estar-no-mundo, que a infelicidade de existir. 0 pecado é destino interiorizado. Por causa disto também a salvação vem ao homem de "outro lado", de "lá do alto", por uma pura magia libertadora, sem ligação com responsabilidade, nem mesmo com a personalidade do homem. (RICOEUR, 2008, 8)

Vários padres da Igreja (santo Irineu, por exemplo) combateram a gnose afirmando que o homem foi criado diretamente por Deus e essencialmente bom, estando aberto à perfectibilidade (Cf. GILSON, 2001, 35). A princípio, Agostinho filia-se a essa tradição afirmando que o pecado é um problema moral, fruto do mau uso do livre-arbítrio, afastando-se da visão trágica em que o homem é vítima de um deus cruel. Porém, em sua polêmica contra Pelágio, Agostinho foi mudando de posição. Segundo Ricoeur, é no Tratado a Simpliciano de 397 que Agostinho usa pela primeira vez o conceito de culpabilidade herdada que estabelece uma dívida do homem para com Deus, que pode perdoá-la ou cobrála, sendo uma arrogância do devedor querer determinar ao credor a quem deve cobrar ou perdoar.

O tema do pecado original, ganha uma elaboração mais acabada na obra Cidade de Deus. Nela, Agostinho enreda não só toda humanidade na queda de Adão, mas o próprio Deus torna-se culpado por nossa natureza pecaminosa. Agostinho argumenta que o homem recebeu uma natureza intermediária entre os anjos e os animais, cabendo-Ihe escolher a qual delas seguiria. Se o homem obedecesse a Deus

juntar-se-ia à sociedade dos anjos e conseguiria para sempre a beatitude eterna sem passar pela morte, mas se, abusando da sua livre vontade pelo orgulho e desobediência, ofendesse o Senhor seu Deus, condenado à morte viver à maneira dos animais, escravo das paixões e, votado, após a morte, a eterno suplício (AGOSTINHO, 2000, 1139).

Mas por que Deus nos teria dado tal natureza? Não saberia que inevitavelmente viríamos a pecar? A esta conclusão lógica, também chega Agostinho: "Deus não ignorava que o homem viria a pecar e que, votado à morte, viria a gerar filhos destinados à morte" (AGOSTINHO, 2000, 1141). Portanto, a escolha do homem "abusando da sua livre vontade", não é tão livre assim e ganha ares de destino: se Deus sabia que a queda do homem iria ocorrer, era Doutor em Filosofia pela PUC-SP e professor titular da Universidade Estadual de Santa Cruz UESC. Brasileiro, residente em Ilhéus - Bahia. Email: josil@uesc.br 
inevitável que este caísse, do contrário, o homem provaria que Deus estava errado a seu respeito, o que não é possível. Nesse sentido, Hamacher (2002) estaria certo por inscrever a culpa dentro de uma história universal, cuja origem seria o próprio Deus. Deus seria o culpado pela culpa de seus filhos, ou seja, a culpa humana do pecado original seria, em última instância, resultado da culpa/falha do próprio Deus, que nos fez culpados².

O livre-arbítrio de Adão tem um limite, somente o próprio Adão pode ser responsabilizado por seus atos. Mas Agostinho transforma o erro de Adão em maldição hereditária: "o que não passava de uma pena para os primeiros homens pecadores, tornou-se natureza para todos os seus descendentes" (AGOSTINHO, 2000, p. 1161). Ou seja, cruzamos a linha que separa o mal moral do mal metafísico, o pecado passa a ser "natureza para todos os descendentes", como ocorre no mito. O que era caráter, torna-se destino cego e hereditário. "E aquilo que tornou o homem, não quando foi criado mas quando pecou e foi castigado, transmitiu-o ele aos seus descendentes no que diz respeito à origem do pecado e da morte" (AGOSTINHO, 2000, 1162).

A humanidade condenada não pode resgatar sua dívida pelo pecado de Adão, não tendo como voltar atrás ou mudar seu destino. A única possibilidade que se abre é a do perdão da dívida, que é arbítrio de Deus, sobre o qual a criatura condenada à morte eterna nada pode fazer. "E essa morte, retribuição do pecado, obtém por vezes a remissão total da sua dívida" (AGOSTINHO, 2000, 1169). Se falta explicação que justifique porque alguns são eleitos e outros condenados, o mesmo não se aplica à condenação que é justificada como pagamento da dívida do homem para com Deus. Como observa Ricoeur:

Certamente, para Agostinho, o mistério divino permanece totalmente, mas é o mistério da eleição: ninguém sabe porquê Deus concede a graça a este ou àquele e não a outro. Pelo contrário, não há mistério da reprovação: a eleição é por graça, e a perdição é por direito, e é para justificar esta perdição de direito que Agostinho construiu a ideia de uma culpabilidade de natureza, herdada do primeiro homem, efectiva como um acto, e punível como um crime. (RICOEUR, 2008, 17)

\footnotetext{
2. Nossa discordância em relação à interpretação de Hamacher é que ela é correta para uma visão ortodoxa da teologia, o parasitismo do capitalismo no cristianismo, segundo Benjamin, desenvolveu-se "com base em todas as demais tendências ortodoxas". Esta afirmação abre a possibilidade de que em uma interpretação "heterodoxa" o cristianismo ainda poderia portar um potencial emancipatório.
}

Doutor em Filosofia pela PUC-SP e professor titular da Universidade Estadual de Santa Cruz UESC. Brasileiro, residente em Ilhéus - Bahia. Email: josil@uesc.br 
No entanto, fica sem explicação o papel da salvação diante da prevalência da culpa, ou seja, se como disse São Paulo "onde o pecado se multiplicou, a graça superabundou" $(\operatorname{Rm} 5,20)$, não deveria ser a justificação pela fé a regra e não a exceção? Qual o propósito de aceitarmos a Cristo se isso não nos garante a permanência na graça? Estas questões serão tema da reflexão de santo Anselmo, porém, longe de derrubar a tese da culpa/dívida de Agostinho, irá reformulá-la ampliando sua abrangência, tornando a teologia cristã uma teologia da dívida como veremos a seguir.

\section{A teologia da dívida em santo Anselmo}

Em sua obra Cur Deus homo (Por que Deus se fez homem? Escrita entre 1094 e 1098) Anselmo afirma que seu objetivo principal é dar uma resposta à questão da encarnação de Cristo, ou seja, porque Deus teria se despido de sua onipotência e se tornado homem para pagar nossos pecados. Para responder a tal questão, Anselmo faz uma elaborada argumentação que coloca o pecado original como fundamento da teologia da dívida, ocupando assim, um lugar central na teologia cristã a partir de então. A relação entre Deus e o homem, deixa de ser uma relação criador-criatura, para transformar-se em uma relação credor-devedor. Tal situação é vivida pelo homem como destino já que não há como pagar uma dívida infinita. Como observa Franz Hinkelammert: "Deus cobra do homem uma dívida impagável, porque o homem é culpado do fato de que a dívida seja impagável. A justiça pede que seja cobrada, pese que não seja pagável. Se não há meio de pagar, deve ser paga com sangue" (HINKELAMMERT, 1991, 71).

A teologia de Anselmo rompe com a teologia do cristianismo primitivo reafirmando o princípio contra o qual Jesus tinha lutado: de que se faz justiça através do cumprimento da lei. Para Anselmo, ao contrário, a justiça está em cumprir a lei e pagar o que deve: "Se um homem é chamado de injusto porque não paga a seu próximo uma dívida, muito mais injusto é quem não devolve o que deve a Deus" (ANSELMO, 2016, 48). Mas se a dívida é impagável, mesmo assim é justo cobrá-la? Anselmo responde: "Portanto, a inabilidade do homem para restaurar o que deve a Deus, uma inabilidade que atraiu sobre si mesmo Doutor em Filosofia pela PUC-SP e professor titular da Universidade Estadual de Santa Cruz UESC. Brasileiro, residente em Ilhéus - Bahia. Email: josil@uesc.br 
por não pagar, não exime o homem de pagar; já que o resultado do pecado não pode escusar o pecado cometido" (ANSELMO, 2016, 48). Ora, mas que sentido tem cobrar uma dívida que, na prática, não pode ser paga? A resposta de Anselmo é que se a dívida não pode ser paga isso é um problema do devedor e o credor não pode ter seu direito de reivindicá-la violado. Mesmo assim, poderia ainda se argumentar que, frente à incapacidade do devedor em pagar sua dívida, o credor poderia perdoá-la. Porém, Anselmo equipara justiça ao cumprimento da lei e seria uma injustiça com quem é justo e paga suas dívidas, que o injusto seja premiado com o perdão. Assim, o devedor de uma dívida impagável não pode apelar para misericórdia de Deus e o perdão da dívida, porque, desta forma, Deus estaria sendo injusto. Caímos, desta forma, na paradoxal situação em que nem o justo, que quer pagar a dívida, nem o injusto, que não quer, podem de fato pagá-la, o que os coloca em igual situação. Embora suas intenções sejam diferentes, ambos são igualmente culpados. Portanto, a culpa é universal, já que justos e injustos são igualmente devedores e Deus não pode exercer sua misericórdia por obediência à lei. Assim, a única alternativa é que alguém pague a dívida infinita e cumpra, desta forma, a lei. Mas um homem não pode realizálo, pois só pode pagar dívidas finitas e não infinitas. Deus também não pode, pois não poderia pagar algo para si mesmo. A solução, que dá título à obra, é que Deus se torne homem, em Cristo, para assim, sendo Deus/homem pagar uma dívida infinita, esta dívida se paga com a morte. Deus mata seu Filho para resgatar a dívida.

A substância da investigação era esta, por que Deus se fez homem, com o
propósito de salvar aos homens por sua morte, quando poderia tê-lo feito de
alguma outra maneira. E, por numerosas e positivas razões, demonstrou que a
restauração da humanidade não poderia ter lugar, e não poderia, sem o homem
ter pago a dívida que tinha com Deus por seu pecado. E esta dívida era tão
grande que, embora ninguém mais que o homem devia pagar a dívida, ninguém
senão Deus poderia fazê-lo; de modo que o Redentor deveria ser homem e Deus
ao mesmo tempo. E, portanto, era necessário que Deus assumisse a natureza
humana na unidade de sua pessoa, e assim, o que em sua mera natureza devia,
mas não podia pagar, pudesse pagá-la na pessoa de Deus. (ANSELMO, 2016,
83).

Embora o sacrifício de Cristo possa ser considerado um preço demasiado alto pelo resgate da dívida da humanidade, ao menos nos torna livre do pecado e da culpa. Mas a lógica de Anselmo não opera assim. Cristo não paga a nossa dívida, ele a resgata e coloca a nossa disposição um tesouro no Céu. Cabe a UESC. Brasileiro, residente em llhéus - Bahia. Email: josil@uesc.br 
nós recorrermos a este tesouro para resgatar nossa dívida, ou seja, nós continuamos devendo, só que agora a dívida pode ser paga aceitando Jesus como fiador. Aquele que não aceita a Cristo, continua devendo e sofre a condenação eterna.

Outro aspecto interessante da teologia da dívida de Anselmo é o seu sistema de débito e crédito. Jesus tem um tesouro no Céu para nós usarmos, ou seja, um sistema de crédito. Este crédito possibilita o pagamento de nossas dívidas, mas o crédito não é concedido a qualquer um, é preciso ter "méritos", ou seja, a concessão do crédito passa por uma avaliação se somos ou não merecedores de crédito. Disso resulta um contrato: a aceitação de Cristo como fiador da dívida. Do contrário, continuamos devedores e culpados, isto é, a graça não vem "de graça", há um preço a ser pago. Novamente, como na doutrina do pecado original de santo Agostinho, o que é universal é a culpa e a graça é a exceção. Permanecemos na estrutura mítica de uma condenação que aparece como uma quase-natureza, somos culpados por termos nascido no pecado. Há, porém, uma possibilidade de salvação para o homem ao aceitar o sacrifício de Cristo e, assim, participar do seu tesouro. No final das contas, as dívidas precisam ser pagas de uma maneira ou de outra, não existe perdão.

A teologia de Anselmo introduz no século XI, algumas modificações importantes no pensamento católico que vão preparar o terreno para a Revolução Comercial em curso. A primeira delas é a legitimação dos contratos: dívidas devem ser pagas, não importa se em espécie ou com sangue (a exemplo do judeu Shylock em O Mercador de Veneza de Shakespeare). Tampouco importa se a dívida é impagável, como as dívidas dos países pobres do Terceiro Mundo. A injustiça não está em se cobrar uma dívida impagável, mas em não pagá-la. Tal princípio é uma das bases do capitalismo liberal, ou seja, a garantia dos contratos, sendo a outra, a propriedade privada.

Outra inovação é a linguagem monetária empregada: pecado, culpa e dívida são usados como termos sinônimos. Embora não se fale em somas quantificáveis (já que se trata de uma dívida infinita), os termos "devedor", "credor", "pagamento", "tesouro" e suas variantes “débito", “crédito”, não são usados como metáforas, razão pela qual não serão entendidos igualmente como metáforas quando empregados na teologia protestante. Os condenados ao Doutor em Filosofia pela PUC-SP e professor titular da Universidade Estadual de Santa Cruz UESC. Brasileiro, residente em Ilhéus - Bahia. Email: josil@uesc.br 
tormento eterno são os devedores com suas dívidas impagáveis, cuja culpa não pode ser redimida. Os agraciados são os que desfrutam do tesouro no Céu na forma de crédito infinito.

A modificação da doutrina do pecado original realizada por santo Anselmo mantém-se fiel à teologia de santo Agostinho no que respeita ao pecado hereditário naturalizado e a impossibilidade de redenção da humanidade por seus próprios meios. A novidade está em que, ao contrário de Agostinho que via a possibilidade da graça no arbítrio de Deus, Anselmo institui a possibilidade de salvação pelo mérito, ou seja, do devedor negociar sua dívida assumindo Cristo como fiador. Este novo elemento será visto com reservas na teologia protestante como veremos mais a diante. O que importa aqui é deixar claro como o "parasita", para usar a expressão de Benjamin, foi tomando conta do hospedeiro. Ou seja, como a religião foi ganhando contornos míticos de naturalização da culpa, de destino, ou melhor, de predestinação, retirando do ser humano a possibilidade de rebelar-se contra um sistema que foge completamente ao seu controle e que deve ser aceito como maldição e condenação. Embora ainda se vislumbre a possibilidade de redenção, esta permanece como possibilidade, enquanto a culpa é necessidade. Além disso, assim como ocorre no direito, a religião fixa-se como um sistema punitivo muito distante do "Deus é amor" e de que "o sábado foi feito para o homem e não o homem para o sábado" (Mc 2,27). Doravante, a Lei é Deus e o homem foi feito para lei e não a lei para o homem.

\section{Usura e pecado}

Embora o capitalismo, como um parasita, estava sendo gestado através da teologia católica oficial, este caminho não estava livre de conflitos internos que o impediam de desenvolver-se completamente e só veio a atingir sua plenitude na teologia protestante. A razão dessa resistência está na condenação da usura.

Houve uma época em que se considerava crime grave cobrar juros pelo uso do dinheiro. No princípio da Idade Média o empréstimo de dinheiro a juros era proibido por uma Potência, cuja palavra constituía lei para toda a Cristandade. Essa potência era a Igreja (HUBERMAN, 1983, 45). 
Quem violasse o mandamento da Igreja, não só poderia sofrer a danação eterna, como também punições legais, como multas e perda dos bens. A raiz teológica da condenação da usura pode ser buscada em inúmeras passagens bíblicas, mas também encontrava amparo nas ideias do "Filósofo", que é como Tomás de Aquino se referia a Aristóteles.

Para Aristóteles, o dinheiro é um meio de troca, assim como qualquer outra mercadoria, como o vinho ou o trigo. A sua utilização consiste no seu consumo, portanto, ninguém poderia ganhar duas vezes pela mesma venda. Por exemplo, se vendo o vinho a meu vizinho, não posso the cobrar um adicional pelo "uso" do vinho, o que seria absurdo. Daí que viria o termo "usura", uma cobrança pelo uso.

Com muito mais razão se detesta a prática de cobrar juros, porque nela o ganho resulta do dinheiro propriamente dito e não da finalidade para a qual o dinheiro foi instituído. Ora o dinheiro foi instituído para a troca, enquanto o juro multiplica a quantidade do próprio dinheiro (ARISTÓTELES, Política, 1258b).

Aristóteles considera ainda que realizar comércio com o fim de enriquecer foge à finalidade natural da economia que é prover os bens necessários à vida. A busca desenfreada por riquezas é considerada por ele, como sendo uma outra arte, a crematística, que não é natural, pois visa a riqueza em si mesma. Sendo a possibilidade de acumulação de riquezas infinita, ela é motivada unicamente pela cobiça e leva ao desequilíbrio natural entre as transações (Cf. ARISTÓTELES, Política, 1257a).

O mesmo princípio está presente em Tomás de Aquino, que considera que "receber juros por um empréstimo monetário é injusto em si mesmo, porque implica a venda do que não existe, com o que manifestamente se produz uma desigualdade que é contrária à justiça" (AQUINO, 1990, 601). Portanto, se alguém me pede dinheiro emprestado porque está em dificuldade e eu lhe cobro juros por ter me pagado meses depois, estou cometendo um duplo pecado: primeiro por estar me aproveitando de uma pessoa em dificuldade; segundo por estar querendo vender algo que, por natureza, pertence a Deus: o tempo. O tempo não pode ser vendido ou comprado, simplesmente porque não é uma coisa. 
Esta mentalidade estava em perfeita adequação com uma sociedade cujas trocas comerciais visavam atender às necessidades vitais das pessoas e cujo comércio não envolvia grandes riscos nem o emprego de capital. Esses elementos passam a ser levados em conta nos empreendimentos comerciais dos burgueses dos séculos XV e XVI e, com eles, uma nova mentalidade sobre a usura e os lucros derivados do investimento de capital. Christoph Fleischmann, em sua obra Gewinn in alle Ewigkeit: Kapitalismus als Religion (Lucro por toda eternidade: Capitalismo como religião), traça um cuidadoso estudo histórico de como a mentalidade da Igreja foi se transformando de uma condenação da usura para sua justificação, isso muito antes da Reforma Protestante. Como exemplo, Fleischmann cita Leon Battista Alberti que escreve sobre como administrar de maneira mais eficiente o tempo, pois da administração do tempo advém o sucesso nos negócios. Esta linguagem soa familiar aos modernos que acreditam que time is money, mas sua presença na Itália da Renascença em um ambiente católico, soa algo estranho. O que Fleischmann demonstra é que dentro do próprio ambiente católico já se gestava uma profunda mudança de opinião quanto à prática da usura e do direcionamento da atividade comercial com a finalidade de lucro. Obviamente, embora esse estudo, entre outros, coloque a obra de Weber sob grandes ressalvas, ele mostra como uma elaboração racional das novas práticas burguesas foram sendo desenvolvidas para dar respostas aos imperativos econômicos que surgiam, o que é muito diferente de como certas concepções, por assim dizer, "irracionais" criaram afinidades eletivas com o desenvolvimento do capitalismo. Nesse sentido, poderíamos dizer que A ética protestante e o espírito do capitalismo de Weber visa mostrar justamente como questões teológicas influenciaram nas formas de conduta e não o contrário, 0 que está mais próximo da intuição de Benjamin sobre a universalização da culpa.

\section{A religião do dinheiro}

Para que o capitalismo pudesse se desenvolver era preciso que se adotasse uma forma objetivamente irracional de existência. Nas palavras de Max Weber: 
O homem dominado pela produção de dinheiro, pela aquisição encarada como finalidade última da sua vida. A aquisição econômica não mais está subordinada ao homem, como meio de satisfazer suas necessidades materiais. Esta inversão do que poderíamos chamar de relação natural, tão irracional de um ponto de vista ingênuo, é evidentemente um princípio orientador do capitalismo (WEBER, 1989, 33).

Weber confronta a forma aristotélica de pensar a economia, como meio de satisfazer as necessidades materiais, com a crematística, em que o homem está dominado pela produção do dinheiro como um fim em si mesmo, que inverte a "relação natural", ou seja, o ciclo de reprodução da vida humana, causando, por vezes, o seu contrário, a destruição das próprias fontes de riqueza: o ser humano e a natureza. Tal orientação é classificada por Weber como "irracional" de "um ponto de vista ingênuo", ou seja, o ponto de vista de Aristóteles e Aquino que pensam que a economia tem por finalidade a garantia da vida humana e não a reprodução do capital. Para que a crematística se tornasse a própria lógica do sistema, como uma finalidade sem fim, isto é, como uma finalidade que tem um propósito em si mesma (acumular capital para acumular capital), era preciso uma nova ética que extrai a sua "racionalidade" da religião.

É importante deixar claro que não há uma relação causal entre a ética protestante e o desenvolvimento do capitalismo ${ }^{3}$. Os reformadores não tinham em mente nenhuma "cultura ética", nem reformas sociais ou ideais culturais. "Os resultados culturais da Reforma foram em boa parte consequências imprevistas, e por isso mesmo não-desejadas, do trabalho dos reformadores, muitas vezes bastante divergentes, e até opostas ao que eles realmente desejavam" (WEBER, 1989, 60-61). O que há, portanto, entre Reforma e capitalismo são afinidades eletivas que se reforçam mutuamente e que têm sua origem na doutrina protestante da predestinação que é uma continuidade da teologia de santo Anselmo. Como observa David Brown, "embora Calvino rejeitasse qualquer menção sobre o mérito de nossa parte, é surpreendente como muitos de seus

\footnotetext{
3 Para aprofundar a discussão sobre afinidades eletivas entre a ética protestante e capitalismo ver a tese de doutorado de Allan Coelho, Capitalismo como religião: uma crítica a seus fundamentos míticos-teológicos, páginas 187 a 206, disponível em: http://tede.metodista.br/sspui/handle/tede/324.
} 
pontos de vista formam uma continuidade com os de Anselmo" (BROWN, 2006, 296).

Calvino dá prosseguimento à doutrina de Anselmo de uma culpa universal e da impossibilidade da criatura de ser sujeito de sua própria salvação. Esta posição não é um consenso entre os protestantes. Lutero, por exemplo, postulava que o sujeito humilde poderia ser merecedor da graça, assim como o pecador arrependido. Para Calvino, entretanto, a posição de Lutero estaria em contradição com a absoluta liberdade dos desígnios divinos que não podem ser de maneira alguma influenciados pelo mérito humano, já que, nesse caso, a decisão não seria mais de Deus, mas da criatura culpada. Ora, a graça não tem nada a ver com as realizações ou com a própria fé ou vontade do fiel. Para Calvino, a graça "não é misericórdia, mas predestinação inconcebível por antonomásia, transcendência intangível, e se subtrai a toda atividade religiosa do ser humano e inclusive a toda categoria que tenha algo de emocional e racional" (BLOCH, 1968, 149).

Desta forma, eleitos e condenados já estão predestinados desde toda a eternidade e não há o que possam fazer para mudar tal realidade. "A graça de Deus, uma vez que seus desígnios não podem mudar, é tão impossível ser perdida por aqueles a quem Ele a concedeu como é inatingível para aqueles aos quais Ele a negou" (WEBER, 1989, 71-72). Assim, o culto, ou mesmo a participação na eucaristia, que garantiriam ao fiel católico, a permanência na graça, são negados ao protestante que afasta qualquer suposto poder salvífico dos sacramentos, vistos por eles como um resquício de magia atribuída ao sacerdote. Enfim, como aponta Weber, para o calvinista "não só não havia meios mágicos, como não havia meios" (WEBER, 1989, 73, grifo do autor). Desse modo, o protestante está totalmente abandonado, sem nenhum sinal que manifeste a presença da graça em sua vida. Tal situação motiva uma profunda angústia e solidão, frente a um Deus transcendental e distante, pois a relação do fiel com Deus é sempre individual e a salvação também. A angústia, nesse caso, não é um sentimento psicológico, mas existencial, pois é provocada pela culpa, igualmente transcendental, cuja mancha só pode ser retirada pela graça. É a consciência da condenação e da morte que atormenta o fiel como uma Doutor em Filosofia pela PUC-SP e professor titular da Universidade Estadual de Santa Cruz UESC. Brasileiro, residente em Ilhéus - Bahia. Email: josil@uesc.br 
consequência lógica da doutrina da predestinação, já que não saber-se na graça é permanecer na culpa, pois a dúvida jamais pode ser afastada completamente. Frente a esta situação, o protestante pode tomar duas atitudes distintas de acordo com suas convicções luteranas ou calvinistas:

O crente religioso pode certificar-se de seu estado de graça tanto sentindo-se o receptáculo do Espírito Santo, como o instrumento da vontade divina. No primeiro caso, sua vida religiosa tende para misticismo e para a emotividade, no último, para a ação ascética; Lutero está mais próximo do primeiro tipo enquanto o Calvinismo pertenceu ao segundo (WEBER, 1989, 79).

A ação ascética que move o calvinista é a maneira de permanecer na fé e a forma de sua luta interior para vencer a dúvida, que é vista como tentação demoníaca. Assim, a convicção de estar na graça e o trabalho profissional sistemático e metódico se tornam as formas da espiritualidade calvinista:

Por um lado manteve-se como um dever absoluto, de cada um considerar-se escolhido e de combater todas as dúvidas e tentações do demônio, já que a falta de autoconfiança era o resultado da falta de fé, portanto, de graça imperfeita. (...) Por outro lado, a fim de alcançar aquela autoconfiança, uma intensa atividade profissional era recomendada, como o meio mais adequado. Ela, e apenas ela, afugenta as dúvidas religiosas e dá a certeza da graça (WEBER, 1989, 77).

É dessa forma que o trabalho sistemático e metódico se torna o centro da vida religiosa e o enriquecimento através da atividade profissional ou do emprego eficaz do tempo, torna-se a forma de manifestação da glória de Deus no mundo e de uma vida abençoada. O mundo existe para a glória de Deus e o cristão eleito para aumentar esta glória. Por conseguinte, a vida metódica e disciplinada do ideal ascético dos monges se torna secularizada, na medida em que não é mais uma "fuga" do mundo, mas uma intensa atividade econômica cuja eficácia é medida em termos de riqueza. Nisso o protestantismo afasta-se das ideias medievais sobre o trabalho, que passa a ser visto não como um "mal necessário" para sobrevivência, mas como uma oportunidade de enriquecimento. Logo, querer ser pobre é o mesmo que querer ser doente e a falta de vontade para trabalhar é vista como um sintoma da ausência do estado de graça.

Contudo, a riqueza é causa de certo desconforto entre os protestantes, pois ela pode trazer o ócio e afastar da vida santa, além de poder ser usada para o prazer da carne e do pecado. Portanto, a busca da riqueza devia ser Doutor em Filosofia pela PUC-SP e professor titular da Universidade Estadual de Santa Cruz UESC. Brasileiro, residente em Ilhéus - Bahia. Email: josil@uesc.br 
combinada com a austeridade no plano do consumo. A maneira de manter a vigilância constante contra as tentações que a riqueza traz é através de um estrito uso do tempo em função do trabalho. O tempo não produtivo, o tempo dedicado ao ócio, no sentido grego do termo, ou seja, à vida espiritual ou vida ativa, como definia Aristóteles, às artes, filosofia, música, etc., tudo isso é visto como pecado. O tempo que não se traduz em dinheiro, "a perda de tempo" é vista como o principal e maior dos pecados. "A perda de tempo através da vida social, conversas ociosas, do luxo, e mesmo o sono além do necessário para a saúde - seis, no máximo oito, horas por dia - é absolutamente indispensável do ponto de vista moral" (WEBER, 1989, 112). É assim que o dinheiro se torna a medida do tempo e também a medida da existência, ganhar tempo ou perder tempo é algo que se mede em cifras. Da mesma forma, o dinheiro não existe mais para garantir a vida do crente, mas o crente que vive para o dinheiro.

A ética protestante do trabalho racional e metódico, que coloca como único objetivo da existência a acumulação de riqueza, aliada a frugalidade no consumo e a orientação de todas as atividades da vida a partir da única métrica de tornar os ganhos mais eficazes, funcionou como uma mola propulsora do capitalismo nascente. Ao contrário do entesourador pré-moderno que é movido unicamente pelo desejo de acumular riquezas sem investi-las produtivamente, 0 moderno protestante transforma sua riqueza em capital.

\footnotetext{
E justamente na mesma medida em que a produção se incrementava de maneira consequente e sistemática em virtude do abstrato dever do trabalho em si, o ideal de pobreza de Calvino, aplicado unicamente ao consumo, surtia o efeito de uma formação de capital, enquanto o imperativo da poupança forjou seu compromisso com respeito à riqueza, entendendo-se esta como magnitude emancipada de modo abstrato e que deveria acrescentar-se por mor de si mesma (BLOCH, 1968, 145-146, grifos do autor).
}

Resumindo a argumentação até aqui, a doutrina da predestinação de Calvino provoca um profundo sentimento de angústia, solidão e abandono no fiel protestante frente a um Deus transcendente e indiferente aos sofrimentos humanos. O único modo de aliviar a angústia existencial de não saber-se salvo é o trabalho profissional como forma de aparentar estar na graça, tendo a riqueza material como sinal da benção de Deus na vida do crente. Esta riqueza, porém, não pode servir de subterfúgio para uma vida dissoluta, ao contrário, o fiel deve 
viver para o dinheiro e não o contrário. O uso eficaz do tempo na acumulação de capital é a fórmula que permite a constante vigilância sobre cada ação do sujeito, tornando a vida uma ação racional, metódica e sistemática de busca de otimização dos ganhos.

O modo de vida calvinista em que um ideal religioso ganha a forma de ação racional com relação a fins, mensurável em termos puramente materiais, Weber chama de secularização. Ou seja, da mesma forma que a racionalidade que regula a burocracia estatal e o planejamento no interior da empresa, indicam a entrada na Modernidade justamente por não estarem mais sob o domínio da Igreja Católica tanto na esfera política como econômica; a ética protestante faz o caminho inverso mundanizando a fé. Isso, é claro, não de um modo intencional, mas como uma consequência lógica dos pressupostos teológicos da doutrina da predestinação e da culpa universal. Na perspectiva marxista de Ernst Bloch, a secularização da fé calvinista seria um abandono da proposta de Jesus Cristo, contudo, cabe ressaltar que esse processo já havia sido iniciado muito antes com a universalização da culpa e a teologia da dívida que coloca o cumprimento da Lei no centro da teologia cristã.

Assim, pois, a decisão divina persegue não já a salvação eterna da criatura (parte da qual, como já é sabido, está perdida para sempre), mas o louvor coletivo da glória de Deus, a qual se dá entre os réprobos não menos que entre os justos. Em consequência, Jesus Cristo vem a ser, portanto, essencialmente o renovador da Lei, o fiador ante Deus de todos aqueles que imitem sua ativa conformidade com a vontade de Deus, não é, pois essencialmente um justificador, como na doutrina luterana. De nenhuma maneira se acham, pois, o sacrifício de amor realizado por Cristo nem a misericórdia divina que perdoa os pecados no centro da perspectiva religiosa (BLOCH, 1968, 149).

Obviamente, Weber está mais interessado em demonstrar como a transformação de uma ação racional motivada por valores (Wertrationalität) acaba por tornar-se, de modo não-intencional, em uma ação racional com relação a fins (Zweckrationalität) em seu processo de secularização, criando a ética e as atitudes necessárias ao desenvolvimento do capitalismo. Ernst Bloch que era amigo tanto de Weber como de Benjamin, utiliza a obra de Weber para realizar seu ataque ao calvinismo e é o primeiro a usar o termo "capitalismo como 
religião", que provavelmente inspirou o título do esboço de Walter Benjamin ${ }^{4}$. Em sua crítica, Bloch sentencia:

A consciência religiosa se viu privada da tensão entre o estado de pecado e o estado original, em virtude de uma reforma que, definitivamente, supôs não uma tergiversação, mas 0 total desprendimento do cristianismo e inclusive chegou a estabelecer os elementos de uma "religião" nova, a saber, o capitalismo, entendido este como religião e como igreja de $\mathrm{Mamon}^{5}(\mathrm{BLOCH}, 151)$.

Weber, por seu turno, não deixa de demonstrar certa admiração ao analisar como a ética protestante criou o "espírito do capitalismo", modificando a concepção pré-moderna em relação ao trabalho e ao acúmulo de dinheiro, fornecendo a mentalidade disciplinada e metódica necessária ao desenvolvimento do capitalismo. O processo de racionalização e autonomia crescente das diferentes esferas da vida que levam ao desenvolvimento da ciência, política, direito e economia, entre outras, ocorre simultaneamente ao desenvolvimento de uma nova subjetividade. A conjunção de ambos os processos, na visão de Weber, foram fundamentais para o surgimento do capitalismo moderno.

Em suma, racionalização na esfera da ciência, tecnologia, lei e administração criaram 0 ambiente externo, enquanto uma racionalização independente na esfera da religião e ética criaram uma orientação interna disciplinada e orientada para o trabalho que acabou, por uma grande ironia da história, por ser soberbamente "adaptada às peculiaridades do capitalismo". A racionalização interna e externa foram pré-condições indispensáveis para o desenvolvimento do capitalismo industrial moderno (BRUBAKER, 1984, 27).

Esta fortuita confluência da história ganha um tom mais pessimista quando Weber trata dos desdobramentos do capitalismo nos parágrafos finais de $A$ ética protestante e o espírito do capitalismo, em que se permite tecer alguns "juízos de valor" sobre o desenvolvimento subsequente do sistema.

O puritano queria tornar-se um profissional, e todos tiveram que seguilo. Pois quando o ascetismo foi levado para fora dos mosteiros e transferido para a vida profissional, passando a influenciar a moralidade secular, fê-lo contribuindo poderosamente para a formação

\footnotetext{
${ }^{4}$ Michael Löwy cita a correspondência de Walter Benjamin a Gershom Scholen de 27 de novembro de 1921 em que Benjamin relata ter lido as provas do "Münzer" de Bloch. Cf. LÖWY, 2010.

55 Mamon refere-se ao mesmo tempo a um deus que exigia sacrifícios humanos e é sinônimo de riqueza, aparece nos evangelhos de Mateus 6, 24 e em Lucas 16, 9. 13, em que Jesus diz que não é possível seguir a Deus e ao dinheiro (Mamon).
}

Doutor em Filosofia pela PUC-SP e professor titular da Universidade Estadual de Santa Cruz UESC. Brasileiro, residente em Ilhéus - Bahia. Email: josil@uesc.br 
da moderna ordem econômica e técnica ligada à produção em série através da máquina, que atualmente determina de maneira violenta o estilo de vida de todo indivíduo nascido sob esse sistema, e não apenas daqueles diretamente atingidos pela aquisição econômica, e, quem sabe, o determinará até que a última tonelada de combustível tiver sido gasta. De acordo com a opinião de Baxter, preocupações pelos bens materiais somente poderiam vestir os ombros do santo "como um tênue manto, do qual a toda hora se pudesse despir". O destino iria fazer com que o manto se transformasse numa prisão de ferro (WEBER, 1989, 131).

Diferente do puritano que "queria tornar-se um profissional", nós "tivemos que segui-lo" pelo próprio desenvolvimento econômico do capitalismo que não deixa mais espaço para liberdade nem para o trabalhador, que se vê obrigado a vender sua força de trabalho sob condições cada vez mais deploráveis, nem para o detentor do capital, sujeito aos humores do mercado. Como aponta Walter Benjamin, "nisso reside o aspecto historicamente inaudito do capitalismo: a religião não é mais reforma do ser, mas seu esfacelamento. Ela é a expansão do desespero ao estado religioso universal, do qual se esperaria a salvação" (BENJAMIN, 2013, 22). O capitalismo, como religião universal, tornou-se uma prisão de ferro, cujo mecanismo que se autorreproduz não precisa mais da antiga ética protestante como suporte. A autonomia do sistema torna-se prisão para o ser humano, forma de "desesperação universal".

Décadas mais tarde, em 1955, Victor Lebow em seu famoso artigo sobre a competição dos preços, celebra a nova espiritualidade do sistema capitalista: o consumismo. Para Lebow, o consumo de mercadorias não deve estar orientado para satisfação das necessidades vitais dos seres humanos, mas deve tornar-se um ritual e a principal orientação de nossas vidas como forma de acelerar a produção. Ao invés de uma jaula de ferro, Lebow nos vê como consumidores felizes em uma gaiola dourada. $O$ significado de nossas vidas se traduz em consumir, tudo se torna uma finalidade sem fim, um mero girar a roda sem sair do lugar em um eterno retorno do mesmo.

Nossa gigantesca economia produtiva demanda que nós façamos do consumo nosso modo de vida, que convertamos o comprar e o uso de bens em rituais, que busquem nossa satisfação espiritual, ou satisfação do nosso ego, no consumo. A medida de status social, de aceitação social, de prestígio, é agora encontrada em nossos padrões de consumo. O próprio significado e importância de nossas vidas hoje se expressam em termos de consumo. (LEBOW, 1955). 


\section{Capitalismo, eterno retorno e progresso}

A acumulação primitiva, dizia Marx, desempenha na Economia Política um papel análogo ao pecado original na Teologia, pois, através da acumulação primitiva, o capitalismo pôde tornar-se o modo de produção dominante, da mesma forma que o pecado original universalizou a culpa. E com a ironia que Ihe é característica, Marx não deixa de observar a contradição entre aqueles que foram condenados "a ganhar o pão com o suor de seu rosto" e os que se livraram do trabalho. "E desse pecado original data a pobreza da grande massa que até agora, apesar de todo seu trabalho, nada possui para vender senão a si mesma, e a riqueza dos poucos, que cresce continuamente, embora há muito tenham parado de trabalhar" (MARX, 1996, 261). A partir do momento em que o capitalismo se institucionaliza através dos mecanismos de mercado garantidos pela ordem legal e política, já não se faz necessário uma ética ou religião qualquer, já que as mesmas se tornam o próprio éthos do sistema. Como observa Benjamin,

A transcendência de Deus ruiu. Mas ele não está morto; ele foi incluído no
destino humano. Essa passagem do planeta "ser humano" pela casa do
desespero na solidão absoluta de sua órbita constitui o éthos definido por
Nietzsche. Esse ser humano é o ser super-humano [Übermensch], o primeiro
que começa a cumprir conscientemente a religião capitalista (BENJAMIN, 2013,
22).

Benjamin retoma aqui as referências de Destino e caráter. Como o destino que pode ser lido nos astros, o planeta "ser humano" agora orbita pela "casa do desespero", pois sabe que nada pode fazer além de cumprir sua órbita sem nunca sair dela, em um eterno retorno. Prova disso é que a transcendência de Deus ruiu, de modo que não há um "fora" do sistema para o qual endereçar nossas forças. Porém, em uma referência direta à famosa frase de Nietzsche, Benjamin contesta que Deus "não está morto", mas foi enredado ao destino humano. Ou seja, nem mesmo como "suspiro dos oprimidos", como diria Marx, ou como "protesto contra a miséria real", a religião subsiste. Agora ela própria foi subsumida dentro do sistema.

Para Benjamin, o super-homem de Nietzsche é o primeiro a cumprir conscientemente a religião capitalista. Segundo Schöttker, "a ideia de superhomem está ligada a ideia de eterno retorno, sem que Benjamin estabeleça 
diretamente esta relação. Apenas uma breve menção é feita à 'duração permanente do culto' como uma 'característica essencial do capitalismo'” (SCHÖTTKER, 2005, 72). Partindo desta hipótese, é possível formar um quadro mais completo sobre a relação que Benjamin estabelece entre capitalismo e eterno retorno.

O conceito de eterno retorno de Nietzsche está ligado à sua crítica aos ideais iluministas da modernidade, particularmente, à ideia de progresso e perfectibilidade do ser humano. A ideia de progresso é vista como uma secularização da teologia, projetando um mundo ideal como futuro, mas ainda permanecendo na dicotomia que opõe o mundo real aos ideais de justiça e igualdade de inspiração cristã. Para Nietzsche, o super-homem seria aquele capaz de viver sem tais projeções e amar a vida tal como ela é, sem idealizações. É o que ele chama de amor fati: "a minha fórmula para a grandeza do homem é o amor fati: nada pretender ter de diferente, nada para a frente, nada para trás, nada por toda a eternidade" (NIETZSCHE, 2008, 42). Esta fórmula reflete-se na ideia de um eterno retorno em que viveríamos sempre mais do mesmo, em que tudo se repete indefinidamente, tal como aparece no aforismo 341 de $A$ gaia ciência:

E se, um dia ou uma noite, um demônio se viesse introduzir na tua suprema solidão e te dissesse: "Esta existência, tal como a levas e a levaste até aqui, vaite ser necessário recomeçá-la sem cessar; sem nada de novo; muito pelo contrário! A menor dor, o menor prazer, o menor pensamento, o menor suspiro, tudo o que pertence à vida voltará ainda a repetir-se, tudo o que nela há de indizivelmente grande e indizivelmente pequeno, tudo voltará a acontecer, e voltará a verificar-se na mesma ordem, seguindo a mesma impiedosa sucessão (...)". (NIETZSCHE, 2000, 219).

Contudo, Benjamin considera que a ideia de eterno retorno de Nietzsche permanece presa ao horizonte mítico sem possibilidade de redenção. O superhomem não apontaria para a possibilidade de um destino diverso daquele da culpabilização reafirmada como sempre mais do mesmo. No Apêndice às teses sobre o conceito de história de 1940, Benjamin escreve:

A concepção fundamental do mito é o mundo como punição - uma punição que primeiro cria seu próprio culpado. O eterno retorno é o castigo projetado em uma escala cósmica: a humanidade deve reescrever o seu texto em incontáveis repetições. (P. Eluard: Répétitions [1922]) (BENJAMIN, 1991, 1234). 
Apesar do heroísmo com que Nietzsche encara o eterno retorno e encoraja os companheiros de jornada de Zaratustra a fazerem o mesmo, isso não faz com que escapem da jaula de aço do capitalismo, apenas que a encarem de modo conformista, como um Sísifo que se agarra estoicamente à faina de rolar a pedra morro acima.

Repensando mais uma vez no século XIX o pensamento do eterno retorno, Nietzsche se apresenta como aquele que cumpre agora 0 mítico decreto do destino. Na verdade, a essência do acontecer mítico é a recorrência. (Sísifo, Danaides). (BENJAMIN, 1991, 1234).

Por mais opostas que possam aparentar, as ideias de eterno retorno e progresso, exibem grande afinidade segundo W. Benjamin. Tal aproximação se justifica dado o caráter mítico de ambas 6 . Segundo Marx, o capitalismo é empurrado para um processo de renovação permanente, tanto pela concorrência, como pela necessidade de aumentar a obsolescência dos produtos e acelerar o consumo. Tudo isso leva ao avanço das forças produtivas com o incremento das tecnologias de produção, o que, por sua vez, leva às crises cíclicas do capitalismo, cada vez mais violentas. Tais crises abririam a possibilidade de uma mudança revolucionária no curso da história, porém, estas também poderiam permanecer como sempre foram: destruição e barbárie.

Posteriormente, as concepções materialistas vulgares da socialdemocracia e do comunismo stalinista desenvolvem uma concepção mecânica do progresso rumo ao socialismo, em que bastaria esperar o curso natural da história que levaria à inevitável vitória do proletariado. O progresso toma a forma do destino mítico capaz de seduzir as massas a acreditarem que a culpabilização seria o meio de redenção, sem se darem conta que cada passo em direção ao progresso é igualmente avanço em direção à destruição do ser humano e da natureza. Tal crença no futuro permanecerá enquanto "tome a seu serviço a teologia" que hoje "é reconhecidamente pequena e feia e não ousa mostrar-se" (BENJAMIN, 1987, 222). Assim, a fé no progresso se reveste de uma roupagem "científica" como lei da história, que oculta o seu caráter mítico

\footnotetext{
${ }^{6}$ Como aponta Michel Löwy "a desmistificação do progresso devia ocupar um lugar importante no Livro das Passagens (Passagen-Werk), como se pode constatar pelas numerosas notas a esse respeito, não apenas na seção intitulada 'Theorie des Fortschritts' mas também na seção sobre Baudelaire e outras" (LÖWY, 1990, 190-191).
} 
de religião secularizada. Nas Teses sobre o conceito de história, Benjamin mostra o quão danosa pode ser a crença no progresso para a classe operária, que se viu desarmada na luta contra o fascismo pela visão equivocada de seus líderes políticos.

O conformismo, que sempre esteve em seu elemento na socialdemocracia, não condiciona apenas suas táticas políticas, mas também suas ideias econômicas. E uma das causas do seu colapso posterior. Nada foi mais corruptor para a classe operária alemã que a opinião de que nadava com a corrente. O desenvolvimento técnico era visto como o declive da corrente na qual ela supunha estar nadando. Daí só havia um passo para crer que o trabalho industrial, que aparecia sob os traços do progresso técnico, representava uma grande conquista política. A antiga moral protestante do trabalho, secularizada, festejava uma ressurreição na classe trabalhadora alemã (BENJAMIN, 1987, 227).

Aliada a essa concepção de progresso está a ideia de um tempo vazio e homogêneo, não como eterno retorno, mas como processo cumulativo que se dirige ao futuro. A esta imagem, Benjamin opõe a do anjo da história que tem o rosto dirigido para o passado, de modo que,

onde nós vemos uma cadeia de acontecimentos, ele vê uma catástrofe única, que acumula incansavelmente ruína sobre ruína e as dispersa a nossos pés. Ele gostaria de deter-se para acordar os mortos e juntar os fragmentos. Mas uma tempestade sobre do paraíso e prende-se em suas asas com tanta força que ele não pode mais fechá-las. Essa tempestade o impele irresistivelmente para o futuro, ao qual ele vira as costas, enquanto o amontoado de ruínas cresce até o céu. Essa tempestade é o que chamamos progresso (BENJAMIN, 1987, 226).

Assim, podemos concluir que o capitalismo como religião produziu duas concepções míticas de história: o eterno retorno do mesmo e a concepção de um progresso indefinido rumo a um futuro impossível de ser alcançado, pois seu processo cumulativo só produz um "amontoado de ruínas que cresce até o céu". Uma visão revolucionária da história precisa romper com ambas as concepções míticas que, no fundo, são diferentes expressões de um mesmo processo culpabilizador do capitalismo que condena igualmente a humanidade e a natureza a continuarem realizando sua autodestruição. Tal processo só é possível por pensarmos a história sem sujeito, com leis mecânicas inexoráveis, como ocorre no mito, em que as próprias realizações humanas voltam-se contra seu criador como se tivessem vida própria.

Para romper com as concepções míticas da história, se exige do materialista histórico um conceito de presente "que não é transição, mas para no UESC. Brasileiro, residente em llhéus - Bahia. Email: josil@uesc.br 
tempo e se imobiliza. (...) O historicista apresenta a imagem 'eterna' do passado, o materialista histórico faz desse passado uma experiência única" (BENJAMIN, 1987, 230). Assim, o presente não é pensado como uma etapa em direção ao futuro glorioso da humanidade, mas como redenção de um passado oprimido. Tal redenção não é obra do "destino" ou das "leis da história", mas da luta da própria classe oprimida. Pois, "o dom de despertar no passado as centelhas da esperança é privilégio exclusivo do historiador convencido de que também os mortos não estarão em segurança se o inimigo vencer. E esse inimigo não tem cessado de vencer" (BENJAMIN, 1987, 224).

\section{CONCLUSÃO}

Retomando o percurso realizado até aqui, podemos afirmar que, embora Benjamin não tenha desenvolvido completamente as intuições presentes em Capitalismo como religião, elas tampouco foram abandonadas no decorrer de sua obra, reaparecendo em suas reflexões associadas aos temas da culpa, mito, eterno retorno, modernidade e progresso, só para citar alguns. No decorrer deste artigo, buscamos seguir as pistas deixadas por Benjamin para compor um quadro em que fosse possível articular a ideia de capitalismo como um culto culpabilizador associada ao desenvolvimento do cristianismo ortodoxo que se afasta de suas origens históricas para tornar-se um mito. É sob a forma de mito que o cristianismo pode compor o éthos, ou melhor, a religião, em sua forma secularizada, do capitalismo.

A expressão desse universo mítico culpabilizador aparece na compreensão da história ora como eterno retorno, ora como progresso indefinido rumo ao futuro, entendido como um processo mecânico. Ambas as versões partilham de uma concepção de tempo vazio e homogêneo que se desdobra em um contínuo como círculo ou espiral.

Enquanto Capitalismo como religião permanece como um diagnóstico sombrio de nossa época, talvez sob o peso da influência de Weber, nas Teses sobre o conceito de história Benjamin formula um conceito ao mesmo tempo crítico e capaz de romper com as amarras do mito do progresso que serviu de Doutor em Filosofia pela PUC-SP e professor titular da Universidade Estadual de Santa Cruz UESC. Brasileiro, residente em Ilhéus - Bahia. Email: josil@uesc.br 
ideologia tanto ao fascismo quanto ao materialismo vulgar. Tal conceito nos coloca novamente como sujeitos da história, como seus produtores e responsáveis, não só pelas gerações futuras, mas também de redimir o passado e todos aqueles que morreram na luta contra a opressão. Dessa forma, podemos romper com o fetichismo do mercado capitalista que se apresenta como um deus a controlar o futuro humano. A forma de romper com o mito está em reconhecer que não existe nenhum atavismo que nos obrigue a continuar com as estruturas culpabilizantes que nos impõem sempre novos sacrifícios em nome de falsas promessas sempre renovadas. Para tanto, basta ouvirmos o apelo que nos dirige o passado.

O passado traz consigo um índice misterioso, que o impele à redenção. Pois não somos tocados por um sopro do ar que foi respirado antes? Não existem, nas vozes que escutamos, ecos das vozes que emudeceram? Não têm as mulheres que cortejamos irmãs que elas não chegaram a conhecer? Se assim é, existe um encontro secreto, marcado entre as gerações precedentes e a nossa. Alguém na terra está à nossa espera. Nesse caso, como a cada geração, foi-nos concedida uma frágil força messiânica para a qual o passado dirige um apelo. Esse apelo não pode ser rejeitado impunemente. O materialista histórico sabe disso (BENJAMIN, 1987, 222). 


\section{REFERÊNCIAS}

AGOSTINHO. A cidade de Deus. Lisboa: Fundação Calouste Gulbenkian, 2000.

ANSELMO. Cur Deus Homo. Madrid. Ivory Fall Books, 2016.

AQUINO, Tomás. Suma de Teología. III, parte II-II (a). Madrid: Bibliteca de Autores Cristianos (BAC), 1990.

ARISTÓTELES. Política. Lisboa: Vega, 1998.

BENJAMIN, Walter. Capitalismo como religião, São Paulo: Boitempo, 2013.

Destino e caráter. Tradução de João Barrento. Covinhã: LusoSofia, 2011, disponível em:

http://www.lusosofia.net/textos/benjamim walter destino e caracter.pdf.

. Gesammelte Schrifiten. Volume I, Tomo I. Organizado por

Rolf Tiedemann ed Hermann Schweppenhäuser, Frankfurt am Main: Suhrkam, 1991.

. Para una crítica de la violencia. Buenos Aires: Editorial Leviatán, 1995.

. Teses sobre o conceito de história. In: Obras escolhidas, Vol. 1. São Paulo: Brasiliense, 1987, pp. 222-232.

BLOCH, Ernst. Thomas Münzer: teólogo de la revolución. Madrid: Editorial Ciencia Nueva, 1968.

BROWN, David. Anselm on atonement. In: DAVIES, Brian \& LEFTOW, Brian (Orgs.). Cambridge Companion to Anselm. London: Cambridge Universety Press, 2006, pp. 270-302.

BRUBAKER, Rogers. The Limits of Racionality: An Essay on the social and moral thought of Max Weber. New York: Routledge, 1984.

FLEISCHMANN, Christoph. Gewinn in alle Ewigkeit: Kapitalismus als Religion. Zürich: Rotpunktverlag, 2010.

GILSON, Etienne. A filosofia na Idade Média. São Paulo: Martins Fontes, 2001. HAMACHER, Werner. Guilt history. Benjamin's "Capitalism as religion". Diacritics, vol. 32, n 3-4, 2002, pp. 81-106.

HINKELAMMERT, Franz J. Hacia una crítica de la razón mítica - El laberinto de la modernidad. San José: Arlekín, 2007. 
Sacrificios Humanos y sociedad occidental: Lucifer y la bestia. San José, Costa Rica: DEI, 1991.

HUBERMAN, Leo. História da riqueza do homem. Rio de Janeiro: Zahar Editores, 1983.

LEBOW, Victor. Price competition in 1955. In: Journal of Retailing, Spring, 1955. Disponível em: https://www.gcafh.org/edlab/Lebow.pdf.

LÖWY, Michel. Romantismo e messianismo. São Paulo: EDUSP/Perspectiva, 1990.

MARX, Karl. O Capital: Crítica da Economia Política, Volume I, Tomo 2, São Paulo: Nova Cultural, 1985 (Col. Os Economistas).

NIETZSCHE, Friedrich. A gaia ciência. Lisboa: Guimarães Editores, 2000.

Ecce homo. Tradução de Arthur Mourão, Covilhã: Universidade da Beira Interior, 2008. Disponível em:

http://www.lusosofia.net/textos/nietzsche friedrich ecce homo.pdf

RICOEUR, Paul. O pecado original: estudo de significação. Tradução de José M. S. Rosa. Covinhã: LusoSofia, 2008, disponível em:

http://www.lusosofia.net/textos/ricoeur paul pecado original estudo de signifi cacao.pdf

SCHÖTTKER, Detlev. Kapitalismus als Religion und seine Folgen. Benjamins Deutung der kapitalistischen Moderne zwischen Weber, Nietzsche und Blanqui. In: WITTE, Bernd e PONZI, Mauro (eds.). Theologie und Politik. Walter Benjamin und ein Paradigma der Moderne. Berlin: Erich Schmidt Verlag, 2005, pp. 70-81.

WEBER, Max. A ética protestante e o espírito do capitalismo. São Paulo: Pioneira Editora, 1989. 